\title{
Problems of residential building facilities in the Czech Republic
}

\author{
Dagmar Kutá ${ }^{1, a}$, Jan Česelský ${ }^{2, b}$ \\ ${ }^{1}$ Dagmar Kutá, Ing. arch., VŠB - TU Ostrava, Faculty of Building, department of Civil Engineering, Ludvíka \\ Podéště 1875/17, 70833 Ostrava-Poruba, \\ 2 Jan Česelský, Ing., Ph.D., VŠB - TU Ostrava, Faculty of Building, department of Civil Engineering, Ludvíka \\ Podéště 1875/17, 70833 Ostrava-Poruba, \\ a dagmar.kuta@vsb.cz \\ a jan.ceselsky@vsb.cz
}

Keywords: Residential building, non-residential premises, common areas, house facilities, area for basement cubicles, area for common storage of bicycles and prams.

Abstract. The submitted paper deals with the house facilities in residential buildings which is often marginalized when solving problems of residential buildings and their areas. However, the house facilities are one of the factors having a substantial effect on quality of using the residential buildings and subsequently on the quality of life. First of all, it is important to define the house facilities properly. The paper deals primarily with spaces for storage bicycles and baby carriages and basement boxes. The standard base for designing these spaces is not suitable enough for a contemporary user and hence the comparison with real values and real utilization of these areas is necessary. In conclusion, the problems are evaluated in context with functional utilization of residential building facilities.

\section{Introduction}

It is necessary to design the facilities for provision of economic and technical operation of residential building. According to ČSN 7343 01, the mandatory spaces of the house facility such as an area for storing prams, bicycles and wheel chairs, rooms for storage things that are not part of a flat, spaces and equipment for heating in houses with central heating, the space for fuel in houses with local heating, the space for storage of unobjectionable garbage in terms of hygiene and fire prevention, lay-byes and parking areas, garage parking for passenger cars. Residential buildings may have other premises and facilities namely a housekeeping and storage room, a cleaning room with sink and hot water outlet, linen drying room perhaps even laundry and ironing room, facility for beating carpets, a room for assembling inhabitants with multi-purpose utilization, customization of flat roofs for recreational purposes or for linen drying. This paper is primarily concerned with the basement cubicle areas, common storage for bicycles and prams. These areas should be a frequently discussed topic in designing both new residential buildings and in their reconstructions.

For correct understanding of the terminology of the facilities, the terms such as housing unit facilities and collective spaces must be explained so as to avoid their mutual confusion. Housing unit facilities are defined as rooms complementing the dwelling rooms and which are used to provide communication, personal hygiene, cooking and other functions necessary for permanent utilization of a flat. Collective spaces, parts and facilities in the house are spaces, parts and facilities in the house designed for sharing.

The ČSN 734301 standard is not binding and it does not present the terms such as collective spaces. Conversely, the Regulation No. 20/2012., Coll. on technical requirements for buildings issued by the Ministry of Regional Development is binding.

The facilities in residential buildings are often marginalized when solving problems of residential buildings and their premises. The facilities are the factors having a substantial effect on quality of using the residential buildings and subsequently on the quality of life. 


\section{Dimensioning and utilization of basement cubicles and spaces for storage of bicycles and prams}

While in the period of development in housing estates, it was common that a basement cubicle, among others, was designed in each new house; these spaces serve now for other purposes in the better case. The initial intended function of these spaces was to store food, conserves or various clubs could have established clubrooms, workshops or fitness centres in larger areas. But times have changed over the years. Due to easily available food in supermarkets, it is not necessary to store durable food, potatoes, etc. Also social integration of population within the framework of hobby groups and clubs in public multi-purpose buildings there is no reason to build them in residential building spaces. The basement cubicle area should be dimensioned to $1.5 \mathrm{~m}^{2}$ per housing unit according to ČSN 7343 01. Based on more detailed analysis of the basement cubicle area, depending on needs of contemporary user, it is possible to come to a conclusion that the sufficient size of the individual basement cubicle must have minimum floor space dimensions $1.9 \times 1.1 \mathrm{~m}$ where it is necessary to meet the requirements for both dimensions.

According to the rule of the house, it is clearly defined how the residential building appurtenances should be utilized. The residential building facilities are only used for purposes corresponding to their operation and intention so that the rights of other tenants in the house cannot be limited. Placing or storing any objects is not permitted in collective spaces except for those for which the spaces are designed (e.g. prams in pram space, bicycles in bicycle space, etc.). For this reason, one of the residential building spaces that retained its function is the area for storing bicycles and prams.

According to ČSN 7343 01, the space for storing bicycles and prams is dimensioned to approx. 0.5-0.7 $\mathrm{m}^{2}$ per one dwelling unit, however, with regard to user's needs according to the Metodika SBToolCZ, the evaluation of residential buildings in terms of user's convenience the space for collective storage of bicycles and prams should have a minimum floor area according to Table [1]:

\begin{tabular}{|l|l|}
\hline $\begin{array}{l}\text { Number of flats in } \\
\text { building }\end{array}$ & Minimum area $\left[\mathbf{m}^{2}\right]$ \\
\hline one-family house & 3 \\
\hline$<10$ & 10 \\
\hline 10 to 30 & 20 \\
\hline 31 to 50 & 30 \\
\hline$>50$ & 40 \\
\hline
\end{tabular}

Tab. 1. Minimum floor area of the space for collective storage of bicycles and prams

These areas are not utilized in a number of residential buildings at all. This can utilized e.g. for establishing a photographic studio, a music band room or a mini-market for a cheap leasehold. But the settlement on utilization of empty spaces with tenants and the housing co-operative is crucial. It is not customary that the spaces are let as independent units so it is always necessary to consider what and where anything can be implemented. However, due to increasing trend towards the utilization of bicycles in traffic and creation of new cycle paths, it is surely more suitable to find solutions for utilization of these spaces that would be aimed at supporting the initial plan for utilization of these spaces as the storage of bicycles. 

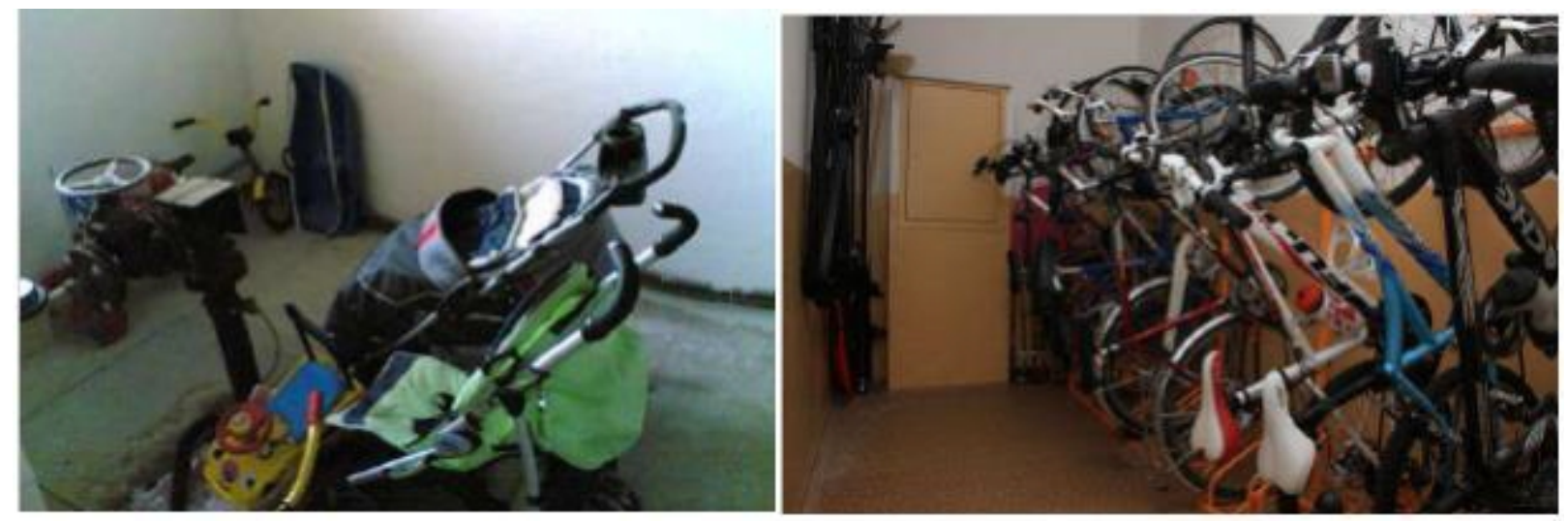

Fig. 1. Functioning, but neglected area for bikes and strollers
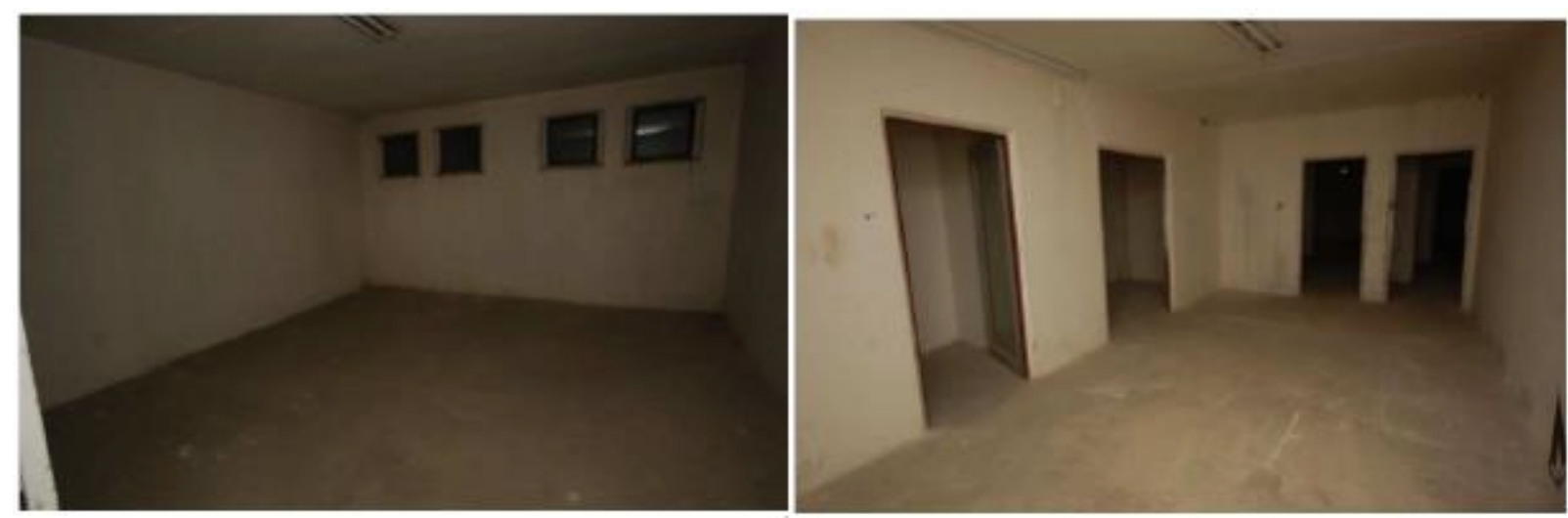

Fig. 2. Exit premises house a residential building - a former common room for bikes and strollers, laundry and drying

\section{Designing the spaces for storing bicycles and prams in new future buildings according to technical requirements}

Current technical requirements for building are the document that substantially influences the form of new buildings. These are currently updated. In the field of traffic serviceability, the regulation being prepared indicates the establishment of bicycle parking racks for the first time. It is just a recommendation where there is no specification providing sufficient quality of bicycle parking racks established. It is necessary to provide the availability of bicycle space without carrying bicycles upstairs and locking the bicycles in spaces shared by a larger number of users must be possible. Bicycle parking racks in residential buildings must be roofed-over to be able to use them for storing bicycles also in winter. The number of parking places proposed for bicycles in residential buildings ( 1 place per $120 \mathrm{~m}^{2}$ of floor area) is derived from the number of bicycles held in households (1.5 bicycles per household in Prague) as roughly one third of the requirement valid in the Netherlands and (per occupied area) one tenth of the requirement valid for cars. The proposal provides larger houses with freedom whether a bicycle room is to be established, a suitable part of collective spaces is utilized, or the place to store bicycles is reserved in garages - the main thing is that the given place is created. 
The full quotation of the proposal for changes to the paragraph in the Technical Requirements for Building from 14.2. 2014:

1. Buildings are usually provided with areas for storing bicycles with the capacity according to a particular intention and location of a building. Areas for parking bicycles are established namely at civic amenities.

2. Surfaces for parking visitors' bicycles are established with public access and they must afford opportunity to lock the bicycles. It is recommended establishing approximately one parking place per bicycle per ten parking places for cars.

3. The places for storing bicycles of permanent users of building are usually established beyond the public area. This area must be accessible from a street or access road without using a staircase or lift. Minimum reserved area is $1.5 \mathrm{~m}^{2}$ per one parking place. If a special room is reserved for storing bicycles, it must have an area of $4 \mathrm{~m}^{2}$ at least and and width 1.5 metre at least. If no special room is reserved for storing bicycles, and if more than 5 dwelling units share the area for storage of bicycles or if it is an area in the building not intended for dwelling, locking the bicycle must be possible.

4. For buildings designed for dwelling, it is necessary to establish the area for storing bicycles to the extent of 1 parking place for each started $120 \mathrm{~m}^{2}$ of the floor area (however, maximum 2 places per unit). This space must be roofed-over. If the requirements for storing bicycles according to (3) are met by basement or garage appropriate for the dwelling unit, it is not necessary to establish an area for bicycle storage [2].

\section{Conclusions}

The concept of a building is always a natural response to the user's needs so the contents of residential building facilities cannot stem from fixed principles. Moreover, it is necessary to realize that developers determine the contents of residential building facilities especially with regard to the highest possible gains from their investments. Before designing layouts of a building and flat, it is necessary to clarify the demands for operational linkages, functional and areal requirements. Therefore, it is necessary to think about the necessity of some spaces in residential buildings and possibilities of utilization for other more convenient purposes for the inhabitants of the building. However, sustainability must always be kept in mind and not to design functions to these spaces that will lose their usefulness and usability after some time and return to the same situation in which they are found at the outset.

\section{Acknowledgement}

The work was supported by the Student Grant Competition VSB-TUO. Project registration number is SP2015 / 127.

\section{References}

[1] Metodika SBToolCZ, hodnocení bytových staveb: (SBToolCZ methodics, evaluation of residential buildings) Uživatelský komfort (User convenience) [online]. Prague, 2012 [quot. 2014-04-02]. Available at: http://www.fce.vutbr.cz/PST/kolar.r/files/SBTo ol_CH09_S06.pdf. Term paper. ČVUT Faculty of Building

[2] Prahou na kole. (Prague by bike) In: Budou v novostavbách kolárny? (Will there be bike rooms in new buildings) [online]. 2014 [quot. 2014-04-23]. Available at: http://prahounakole.cz/2014/02/budou-v-novostavbach-kolarny/ 
